\title{
Peace Making or State Breaking? The Turkish-Kurdish Peace Processes and the Role of Diasporas ${ }^{1}$
}

\author{
LATIF TAS ${ }^{2}$ \\ SOAS, University of London, UK
}

\begin{abstract}
When Erdogan and his party, the AKP, were elected for the first time in 2002, they made several important pledges. None of these have been fulfilled. On the contrary, in recent years the conflict between Turks and Kurds has increased and societal divisions are at boiling point. Unless relations between Turks and Kurds improve, this article contends that it is not possible to resolve the other pressing issues. Under an Erdogan-led regime Turkey has become a rogue state which is now heading towards civil war. This article begins by arguing that there has never been a real Turkish-Kurdish peace process. The outcomes of the research reported here show that the aim of past negotiations - for both the Erdogan-led AKP government and the PKK - is actually to monopolise power and violence, rather than to move towards sustainable peace. The second argument is that diaspora, especially for stateless people, is not just a 'home away from home'. The underlying concern tackled here is how successful negotiations for peace and post-conflict societies can be reached with the help of different stakeholders, including diasporas. The article includes a case history of Kurdish alternative legal practice, which shows that diaspora communities are not only idealistic protesters, but can also act as positive agents and create practical solutions for stateless communities. Finally, the article suggests 15 practical steps towards a sustainable peace.
\end{abstract}

\section{Keywords}

Ethnic conflict, peace, diaspora, Turkey, Kurds, Erdogan, PKK, Middle East Truth is the first casualty of War (Aeschylus, 525 BC - 456 BC)

\section{Introduction}

The conflict between the Turkish state and Kurds is intensifying both in Turkey and in the neighbouring states. Between 1984 and 2015 around 50

\footnotetext{
${ }^{1}$ I would like to thank Prof. Nadje Al-Ali (SOAS, University of London) for her very helpful comments and contribution to this article. I would also like to thank Prof. David Carment, Dr. Aisling Lyon, Dr. Caroline Mawer, Dr. Ariane Sadjed and Dr. Mengia Hong Tschalaer for their comments and help. Some parts of this article have been previously published by Open Democracy in "15 Steps for TurkishKurdish Peace" (Latif Tas, 2016) and "What kind of peace? The case of Turkish and Kurdish peace process (Latif Tas, 2015). An early version of this paper was presented at the following workshops: 'Diaspora as Agents of Global Cooperation ', Kate Hamburger Kolleg, Centre for Global Cooperation Research, 21-22 April 2015, Duisburg, Germany; 'The Kurds in the Middle East: New Developments and Prospects', 24 April 2015, SOAS London Middle East Institute (LMEI), University of London, UK; and 'Diaspora Mobilization for Conflict and Post-conflict Reconstruction: Comparative and Contextual Dimensions', 26-27 November 2015, University of Warwick, UK.

2 Dr. Latif Tas is a socio-legal Research Fellow at SOAS, University of London. His previous positions include being a Research Fellow at Wissenschaftskolleg zu Berlin, Humboldt University and a Visiting Scholar at the Max Planck Institute (MPI) for Legal Anthropology, Germany. He obtained his PhD in Law from Queen Mary, University of London in 2012.
} 
thousand people died as a result of the Turkish-Kurdish conflict. Millions of people were internally and internationally displaced. Hundreds of billions of dollars were wasted on this conflict by the state. Unfortunately there is not only a lack of substantive progress, but also an actual worsening of the situation. In the nine months following the June 2015 Turkish general election and significant political losses for the AKP, six thousand Kurds (including civilians and PKK militants) and 400 Turkish soldiers and police officers have been killed (ICG Report 2016; Reuters 2016; Zalewski 2016).

Seven cities and 17 towns have been significantly affected by ongoing Turkish attacks including bombardment. More than 300 thousand Kurdish people have lost their homes. Large parts of cities in south-eastern Turkey, particularly Cizre, Sur, Nusaybin and Idil have been razed to the ground. Deportations of civilians and destruction of cities and towns continue (BBC 2016a; ICG Report 2016). This is equivalent to, or even worse, than the first year (2011) of the recent conflict in Syria. Unsurprisingly, around 30 percent of the whole Turkish population - not just Kurds - now want to leave the country (Cumhuriyet 2016).

In the recent years, conflicts between Turks and Kurds have increased and societal divisions are at boiling point. One of the main reasons for this is that successive Turkish governments are more interested in maintaining their own power than in any real attempt at peace-making with Kurds. Unlike commonly assumed, Kurdistan Workers' Party (PKK; Partiya Karkerên Kurdistanê) is not the reason for conflicts between Turks and Kurds but, in fact, is the product of this almost century-long problem. Thousands of young people join the PKK voluntarily every year. Forced migration, unequal citizenship and an unsafe living environment means that Kurds are living in exile conditions within Turkey and the neighbouring countries. As long as these exile conditions continue, the PKK and similar organisations will not only exist but will also thrive.

Recent conflicts in Kurdish cities in Turkey show that Kurdish youth organisations are more radical than the PKK. They have even criticised the PKK, about its very 'soft' and 'humanistic' attitude towards the Turkish state. These youth organisations such as the YDG-H (Yurtsever Devrimci Gençlik Hareketi: The Patriotic Revolutionary Youth Movement) and Kurdistan Freedom Falcons (TAK) want more radical actions, to at least equalise the state's actions against Kurds. Two suicide bombs in Ankara in recent months by one of the Kurdish youth organisations, TAK, killed many soldiers and civilians, and showed what kind of action they mean. 
In 2002 when elected for the first time, Erdogan and his Justice and Development Party (AKP) made six important pledges. These were: to develop 'a new pluralistic constitution which respected the ethnic and religious diversity of the country'; to establish a 'strong democracy'; to strengthen the 'rule of law'; to respect 'freedom of speech'; 'to have zero problems with neighbours' and 'to find a peaceful resolution with the Kurds'. None of these pledges have been fulfilled. On the contrary: Turkey is in the $15^{\text {th }}$ year of an Erdogan-led government, and all of these six areas are in a worse state than before. In the 2016 World Press Freedom Index, Turkey is ranking 151. This is lower than Russia, Pakistan, South Sudan, Zimbabwe, Afghanistan and almost the same level as the Democratic Republic of Congo (RSF 2016). In this article, I want to focus primarily on the worsening of the Turkish-Kurdish conflict. Unless this improves, I contend that it is not possible to resolve the other five pledges. The Erdogan-led regime has not only put Turkey into a rogue situation, but the state is now heading towards a civil war (Ellis 2016; Ignatius 2016; Kuntz et al. 2016).

\section{Methodology}

In order to explore individual and family Kurdish experiences in different diasporas and their involvement in homeland politics, conflict and peace, I carried out multi-sited ethnographic qualitative research (as described in Marcus 1995) between December 2012 and March 2016. Multi-sited research technique are suitable to capture the transnational flow of Kurds that are dispersed across Middle East and Europe. The fact that Kurds are stateless. This methodological approach capture the informal flow of people, knowledge, and power across nation-boarders. This included four focus groups and 52 in-depth, open-ended qualitative interviews involving individuals originating from different Kurdish regions. The research involved a total of 85 Kurdish adults, of whom 45 were women and 40 were men. These individuals were currently living in Turkey (Istanbul and Diyarbakir), Germany (Berlin) and the UK (London). Research participants included political and women's rights activists, MPs, co-mayors, academics, journalists, lawyers, Turkish-Kurdish peace activists and community representatives.

This builds on work I have conducted on Kurdish diaspora organisation and practices in the UK, Germany and Turkey since 2008, as part of my previous research (Tas 2013a, 2013b and 2014a). In addition, reports from different NGOs, brochures and publications from different Kurdish associations were examined; events, seminars and conferences were followed; and speeches and interviews from different Kurdish and Turkish political and military leaders were analysed. 


\section{The arguments of the article}

This article focuses on three interconnected arguments. First, it analyses both the ongoing conflict and also the so-called 'peace process' between the Turkish state and Kurds, especially the PKK and their imprisoned leader Abdullah Ocalan. I want to begin by arguing that there is no real peace process in Turkey. The outcomes of the research reported here show that the aim of negotiations - for both the ruling Justice and Development Party (AKP) and the PKK - is actually to monopolise power and violence, rather than to move towards peace. The second argument presented here is that diaspora, especially for stateless people, do not only occur when people move to 'a home away from home'. Forced migration, unequal citizenship and an unsafe living environment means that even an ancestral homeland can feel like a diaspora. Even though they do not have any state to their name, Kurdish diasporas - both in Turkey and outside - have become increasingly active agents. They are not only idealistic protesters, but can also act as positive agents for the homeland. The links that Kurds in the diasporas have with the international community have effects not only on the conflict, but also on potential 'peace-making', 'peacebuilding' and 'reconciliation' processes within Turkey. The article therefore challenges Benedict Anderson's idea that those who live in diaspora keep themselves safe and avoid personal sacrifices (Anderson 1998). Instead, it is suggested that diaspora can be an active part of both peace and conflict. Thirdly, the article contends that the 'game'-based so-called 'peace process' has further deepened divisions between Turks and Kurds, and opened the door for an escalation of violent conflict. It is argued that, if there is no sustainable peace between Turks and Kurds, there is a strong possibility that the Turkish state could break down, in a similar way to Yugoslavia, Iraq and Syria. Kurds have already established some de facto state institutions in Turkey and in diasporas. A case-study of alternative Kurdish legal practice reported here gives an example of how one of these de facto institutions works. Finally and most importantly, the article suggests 15 practical steps towards a sustainable peace.

\section{The reasons for the recent conflict}

The first sign of the failure of the most recent so-called 'peace process' was seen in almost all Kurdish-populated cities in Turkey on 6-7 October 2014. Around 50 people lost their lives while protesting Turkey state support for the Islamic State's (ISIS) siege of Kobani, a Kurdish town in northern Syria. Syrian Kurds and their main Democratic Union Party (PYD) would not have been able to defend Kobani without support from other Kurds, especially Northern (Turkey) and Southern (Iraq) Kurds. The PYD and the PKK are 
sister parties and support each other. Both have fought for autonomy within Syria and Turkey, respectively (Akbaba 2014; Daglar 2014; Pope 2014). The Turkish government was hoping that the Kurds in Kobane would fail. This could weaken Kurds and leave them with no option but to follow Turkey's wishes. It is important to stress that both the PKK and the PYD have claimed that they have moved away from earlier calls for an independent Kurdistan, and now are asking for autonomy within existing nation states.

In the June 2015 election in Turkey, the People's Democratic Party - HDP (a Kurdish-led party with wider appeal, including among progressive Turks) managed to pass the 10 per cent parliamentary threshold. This gave them Parliamentary power, at least theoretically, thereby threatening both the mono-identity of the Turkish state and also mono-power and exclusive politics of the PKK. Even more than this, it also fundamentally challenged the hegemonic power that the AKP has exercised over more than a decade. The established Turkish state bureaucracy and the AKP have therefore come together, not only to fight against PKK, but also almost against the very existence of Kurds in Turkey and Syria.

Kurdish military victories in Syria and Iraq against ISIS and HDP's electoral victory in Turkey against the Erdogan-led regime, have increased the state's historical fears of a possible of creation of Kurdish state and division of Turkey. Any so-called peace process has now been shelved. The Turkish government instead focused first on destroying the embryonic Kurdish state in Syria; second on criminalising and destroying the legal Kurdish political movements (including HDP) in Turkey; and third on blocking the development of Iraqi Kurdistan into an independent state. For all these reasons, any so-called peace related developments that happened after October 2014 - when any peace process ended, and conflict escalated - were just theatre played out by both the Turkish state and Kurdish political representatives. This theatre in the name of peace includes the work of the so called 'Wise People's Committee's and the Dolmabahce Declaration'.

\footnotetext{
${ }^{3}$ The 'Wise People's Committee' was created on 3 April 2013. There were a total of 63 members of this committee, which aimed to help the development of peace between Turks and Kurds. However, the members of this committee were personally selected by then-Prime Minister, now President, Recep Tayyip Erdogan.

${ }^{4}$ On 28 February 2015, a joint statement about 'peace talks' was issued for the first time by the HDP and representatives of the AKP government. This was known as the Dolmabahce Declaration. However, just weeks after this declaration, Erdogan showed his anger and disagreement with the declaration, which remained part of the 'theatrical' actions of the Erdogan-led AKP. According to this agreement, ten articles were jointly issued by the AKP and HDP representatives. These included: 1 . to make a new, pluralistic and inclusive constitution; 2 . To open a way for Kurds to be part of democratic, legal politics and to remove the current 10 percent threshold; 3 . To disarm the PKK; 4 . To de-centralise Turkey; 5 . To develop a new, more inclusive identity for the Turkish state; 6 . To create a truth and reconciliation committee; 7 . To strengthen the rule of law, to respect freedom of speech and free media; 8 . To give
} 
Since August 2015, several towns in Eastern Turkey (North Kurdistan), have been under 24-hour curfew for months (Amnesty International 2016a and 2016b; Pitel 2016a). This means that civilians either starve or face sniper fire. The UK Green Party (2016) Leader Natalie Bennett described the situation:

Kurdish communities in eastern Turkey have been placed under so-called curfews, some for long periods, which has made it impossible for families to secure food supplies, threatened their access to water and electricity and denied those in need access to medical treatment. Amnesty International has described this as being like 'collective punishment' of these communities.

There is not only a lack of any substantive progress towards peace, but also a worsening of the situation (BBC 2016a). Conflict has spread all over Turkey. The violence is not just between state forces and the PKK militias. There has also been an increase in violence against Kurdish people who live or work in the western cities of Turkey. Many HDP offices have been targeted and burnt by Turkish nationalists and AKP supporters since June 2015. This has led to scores of Kurdish deaths.

In addition to conflict in the Kurdish regions and all over Turkey, between June 2015 and March 2016, Turkey has so far witnessed seven suicide explosions: five by the Islamic State (ISIS); two by the Kurdistan Freedom Falcons (TAK). These have cost more than 300 lives (ICG Report 2016; Karaca 2016). Conditions in some parts of Erdogan's Turkey are not very different than those in Syria under Bashar Al-Assad. If all these attacks were not the result of Turkish state intelligence collaboration, then they were a total intelligence failure of the Turkish state to let these almost identical attacks happen (Letsch 2016a).

Erdogan has used ISIS attacks, which have mainly killed Kurds, as an excuse to start a war, not against Islamic militants, but instead against Kurds in Turkey and Syria (CBC 2016; RT 2016; Tisdall 2016). Instead of retaliating against ISIS militants, Turkey and President Erdogan are once again repeating the unsuccessful military methods used in the last hundred years, in yet another attempt to 'annihilate' the Kurdish militants and their supporters (Cakan 2015).

Making Kurds the scapegoat is always popular among Turkish nationalists and populist politicians who court the nationalist vote. Scapegoating Kurds allows the state to divert attention away from the country's other major social and economic problems. While Erdogan tries to use this card, the PKK also uses Erdogan's anti-Kurdish policies to increase Kurdish nationalism for its 
own hegemony. Within both Turkish and Kurdish societies it has almost become a crime to be anti-nationalist. These developments support the idea that, for both the Erdogan-led AKP government and the PKK, the so-called negotiations were not about risk-taking to make peace - but about riskavoidance to maintain the status quo, and so to maintain the current actors' grasp on power. However, without taking substantial risks, including the risk of losing power, it is effectively impossible to broker peace (Dogan 2016).

Since August 2014, when Erdogan became president, 1,845 court cases have been brought against human rights activists, lawyers, journalists, academics , politicians and even ordinary citizens by Erdogan's lawyers (The Guardian 2016b). He expanded the definition of terrorism and to include almost everybody who is against his authoritarian policies. He said on 5th April 2016: "[those] who pose as academics, spies who identify themselves as journalists, an activist disguised as a politician ... [they] are no different from the terrorists who throw bombs" (Zalewski 2016). Nobody's life is safe, especially Kurdish rights supporters and lawyers. For example, Tahir Elci, a well known human rights lawyer, was killed while he was conducting a press meeting in Diyarbakir, in November 2015. Tens of Kurdish lawyers have been detained (Geerdink 2016). For the Erdogan-led regime almost every criticism can be regarded as a treasonable insult to the Turkish state. This has also been the case for Kurdish (HDP) MPs. Foreign academics and journalists have been deported or their working conditions made difficult for merely criticising Erdogan. For example, a British academic, Christopher Stephenson, who is married to a Turkish woman and has lived in Turkey for 17 years, was caught up in the witch-hunt against the academics' peace petition. When he showed solidarity with three of the academics in pre-trial detention, he was arrested for carrying leaflets advertising a Kurdish New Year event. He was detained and then deported from Turkey (Pitel 2016b). Only after pressure from the British Embassy was he able to return to Turkey.

Before analysing the current conditions in the Middle East and Turkey, and the role of diaspora communities in more depth, I would like to underline that peace negotiations are never easy. Getting started is often - usually - the most difficult thing to do (Tas 2015). Conflict will either be temporarily and conditionally stopped, or may even be continuing (Sumbeiywo 2008). Every peace process is like a piece of theatre. There are many players, actors - from different sides - who do not trust each other. Of course, the different sides have different agendas. Some protagonists may be benefiting directly from the war, and can easily choose to destroy any possible peace process. For example, the fifty thousand men currently employed by the Turkish state as village guards have no incentive to support peace, since peace will probably mean that they will lose their family's livelihood. Losing their job would also 
mean losing the weapon they rely on to 'defend' themselves (Geerdink 2014). Other people may want to be perceived as peacemakers, but only so that they can monopolise power and violence for their own benefit. It is even more difficult when there has been a long war, with trust lost between parties and societies. This is the Turkish, Kurdish and Middle Eastern situation.

\section{The homeland is a diaspora for stateless people}

It would be inappropriate to write about conflict and peace without considering the role of diasporas. In this article, I am using the world 'diaspora' to mean both a place and group of people. I have already discussed elsewhere (Tas 2014a, 2016) that for stateless people, diaspora is not just the 'home away from the original homeland' or 'dispersal of people from their original homeland' described by many researchers (see Connor 1986; Safran 1991; Van Hear 1998; Tölölyan 1996; Cohen 1997; Palmer 1998). Forced internal migration can create diaspora within a nation-state. Continuing state oppression, weak citizenship, differential minority classification and treatment (Ustundag 2016), and an unsafe living environment all mean that even the ancestral homeland can feel like a diaspora. For that reason stateless Kurds do not just have one diaspora, they have double or even triple diasporas (Tas 2016). For example, a Kurdish family from Diyarbakir, in eastern Turkey, may feel as though they are living in a diaspora. When they are forced to move to Istanbul, they are living in a double diaspora. After they migrate to London or Berlin, they are in a triple diaspora. All places feel temporary for them.

'Diaspora' has become an over-used term to refer to almost all migrants, overseas communities, or even travellers who have moved temporarily and voluntarily from their original home. The term 'diaspora' is also used to describe a place away from a community's actual homeland (see Connor 1986; Safran 1991; Van Hear 1998; Tölölyan 1996; Cohen 1997; Palmer 1998). These two definitions of diaspora have made the term lose its actual meaning. For this reason, we should not talk about Turkish, Chinese, German or Indian diasporas in the same way as we would a dispersed, persecuted diaspora groups such as Kurds, Palestinians, Tamils or Roma. The first group of people have an actual homeland and may return voluntarily at any time they want. However the concept of diaspora is different for stateless people, who live a life of exile wherever they are. Their actual homeland may be occupied militarily and ruled by a harsh regime, and their culture, language, traditions and religion may be banned or otherwise restricted. These diasporas are unable to feel safe and live mostly in exile conditions. Many of my Kurdish interviewees describe living in Turkey, and even in the Kurdish regions, as akin to living in exile, even more than it would be in Berlin or London. Those 
that have experienced forced migration and dispersal are unable to return to their homeland, and may also not feel safe even if they live in their imagined homeland. There is no safe homeland for them. This means a homeland can be considered one of the biggest diasporas for stateless people. A Kurdish lawyer from Dersim (a Kurdish and Alevi majority city in Turkey), living in Istanbul told me in November 2015:

Even as a lawyer myself, I am afraid for my life every day in this country because I am Kurdish and an Alevi. Taking on the cases of fellow Kurds persecuted by the State creates a huge threat to me, not only from the State itself but also from my Turkish colleagues. Living and working here is like exile. I am not equal to other Turks. Every day I feel like a second-class citizen, even though I graduated from one of the best law faculties - Ankara University. This is the gurbet [diaspora] within which we have been born.

A Kurdish student from a London university also explained:

The Turkish state does not want us to exist anywhere. Everywhere, including our homeland, even Diyarbakir, has been turned into a diaspora for us. I live in the UK and at least we are allowed to say what we want, despite the fact that the Turkish Embassy and government put pressure on the British authorities to arrest us sometimes when we protest peacefully against Turkish state aggressions against our people... But look at Turkey and Syria, they don't even arrest people, they kill them directly and want Kurds as an ethnic and cultural group to decline, to be wiped out completely. Our Kurdish lands and cities in Turkey are the worst diaspora among them all.

The lack of control in their homeland and weak connections to any real place affect the daily life, culture and identity of many stateless people. This constitutes a strong barrier to the idea of living together peacefully and equally with the hegemonic majority. The conflict and separation begins when one community ignores all other different identities and imposes its own identity and culture on other groups. There is a link between identity politics in Turkey, in terms of casting the Kurd as a terrorist and thus as a threat to national security, which seems to result in the ongoing marginalization.

Around four million Kurds have already been internally displaced in Turkey, and more than one million Kurds from Turkey have moved to Western Europe. Even more are, and will be, affected by the ongoing conflict in Turkey and the Middle East. The Western world, especially European countries, has turned a blind eye to oppressive and totalitarian leaders such as Erdogan in the hope that they will not receive any further refugees and can assimilate those they already have. As long as Erdogan continues to make empty promises, many European countries will continue to crack down on the PKK or Kurds more generally and their activities. European silence about authoritarian regimes is not new. They were silent about Saddam Hussein, 
when he used chemical weapons against Iraqi Kurds. Only when Saddam occupied Kuwait, did the West take any action. However, it is the discriminatory policies of these oppressive leaders that have created the forced migrations in the Middle East and Turkey in the first place. As long as war, conflict and crime continue as a result of their identity and national policies, the tidal wave of more refugees will continue to flow. A recent study by Bosphorus University in Istanbul showed that more than 30 percent of people from Turkey, around 25 million, would like to leave the country because of ongoing political instability (Cumhuriyet 2016).

\section{The history of the Turkish-Kurdish 'peace processes'}

In the last 35 years there has never been a day without war and violence in the Middle East and Turkey. The most recent conflict - which started in March 2011 in Syria and has included Iraq from 2014 and Turkey from June 2015 - has cost around five hundred thousand lives. It has created more than 11 million homeless refugees (BBC 2016b). It is not surprising that all of these wars have disproportionately affected Kurds in terms of displacement and genocides. Kurdish statelessness is a key reason for the direct and indirect discrimination against Kurds in the various nation states that they live in.

In Syria and Iraq, there is currently no rule of law, no consistent authority and, effectively, no state. The Iranian and Turkish states have their own agendas. They are both aiming for a 'big brother' style leadership of the Middle East using Shia or Sunni proxies respectively (Tas 2015). Neither Iran nor Turkey wants to see Kurds united, as since the sixteenth century both are accustomed to using warring Kurdish factions as buffer armies. When Kurds try to move away from this situation, and connect with the international community as we have seen in the recent cases, then the Iranian and Turkish states try new ways to weaken Kurds and keep them divided (Tas 2014a and 2014b). Most recently, at the same time that Turkey was supporting the ISIS against Kurds in the Middle East (Sanchez 2016) and using state violence against Kurds in Turkey, Iran was directly helping and supporting Shia militias fighting in Iraq against both Kurds and ISIS. Both countries are happy to see Kurds divided. There is a famous phrase that says, "if you find two brothers fighting, do not try to separate them, otherwise they will both turn on you" (Sumbeiywo 2008). In the Kurdish case, other countries do not just leave Kurdish factions to fight each other; they add fuel to the flames to make sure that the fighting continues.

All these issues and 'big brother' games demonstrate why it is difficult to talk about any real peace process between Turks and Kurds. There have been some talks about possible peace-talks. These limited talks have not involved 
all the different internal and international stakeholders. Instead, they have only been between two political parties or groups (AKP for Turkey, and PKK for Kurds).

These talks about talks are not new. Around two decades ago, in 1993, the Turkish President Ozal tried to negotiate with the PKK leader Ocalan through various mediators (Ensaroglu 2013; Tas 2015). At around the same time, conservative Prime Minister Suleyman Demirel, during a visit to Diyarbakir, said that Turkey "recognised the Kurdish reality." Following these positive moves, on 20 March 1993, just a day before the Newroz (Kurdish New Year) celebrations, the PKK declared their first - and not their last - ceasefire.

However these positive movements did not bear fruit and the one sided PKK ceasefire ended in June 1993 after a group of PKK militias killed 33 soldiers who had finished their compulsory military service and who were on their way to their home. This failure opened the door for the brutal conflicts of the 1990s. The importance of the 'Kurdish question' was acknowledged in 1995 once again when a progressive Turkish politician, the ex-Prime Minister Mesut Yilmaz, declared that democratisation in Turkey and EU accession could not be achieved in Ankara until the problems in Diyarbakir were resolved. In 1997, Turkish Prime Minister Erbakan made another unsuccessful attempt - one of the results of which was a military coup.

The 'Kurdish question' moved beyond Turkey to become a European and international issue with the capture of the PKK founder and leader, Abdullah Ocalan, in 1999. After this arrest the PKK and many Kurdish leaders were initially paralysed. Until 2004, the PKK were effectively militarily silent. However, this was socially, politically and legally one of the most active times for Kurds and the PKK. According to many of my interviewees in Turkey, Berlin and London, Kurds and the PKK started to learn about the dynamics of international power, and focus on international politics.

The PKK recruited a new cadre of members and reorganised the approach to armed struggle against Turkey. Perhaps even more importantly, the PKK focused on creating social, legal and economic institutions in Turkey, Syria, Iraq and the different diasporas. These institutions were intended to contribute to a possible future Kurdish state, as discussed in a later legal casestudy. Transnational Kurdish mobilisation was created and links were made between different capitals, including Diyarbakir, Istanbul, Berlin, Brussels, London and Paris. Different political parties, associations and unofficial legal courts were created and developed during this militarily silent, but institutionally very active, period. Although the PKK was listed, and so 
banned, as a terrorist organisation by many states 5 , political, social and economic mobilisation continued.

During the same time period, with Ocalan under arrest and the PKK militarily quiet, Turkey felt able to relax militarily. However, the effect of the long war with Kurds had paralysed Turkey socially and economically. Seeking help from the economic crisis, the focus was on achieving EU accession. Turkey promised to meet the Copenhagen Criteria, and in response, Turkey's candidacy was approved in Helsinki in December 1999. Some important constitutional amendments were passed by the Turkish parliament following Ocalan's arrest, including the abolition of the death penalty and of the state of emergency (Tezcur 2010). All of this was, however, before the AKP came to power.

On 3 November 2002, after a decade of coalition government, the AKP achieved an electoral majority and was elected under the leadership of Recep Tayyip Erdogan. Despite the moves towards democratisation, there were no specific constitutional changes recognising the existence of Kurdish ethnicity or language. No positive rights were - or are - accorded to Kurds. Instead, thousands of Kurds remain in prison. Deaths in custody, extrajudicial killings, forced migration, and unequal societal treatment all impact Kurds disproportionately. Ryan (1994) and Wickham-Crowley (1992 and 1994) claim that democratisation can reduce the capacity and organisation of insurgent movement. This is not so if the so-called improvements are shortterm and cosmetic, as is the case for Kurds in Turkey. As long as the underlying reasons for starting rebel movements continue, mobilisation and further radicalisation of those movements also continues. Turkey has historically followed one step forward, two steps back when it comes to the Kurdish issue. This has increased the conflict year by year. Kurds are forced to live in diaspora conditions with unequal citizenship. Kurdish regions have not been supported with economic development and unemployment still remains very high. Silence from the PKK allowed the Turkish state and government to continue to 'wait and see' and apply the old methods of ignorance and assimilation, under the guise of a process of so-called democratisation. Only after the PKK restarted the war on the Turkish state in 2004, did the AKP remember that it had a 'Kurdish problem.' In August 2005, Prime Minister Erdogan claimed that 'the Kurdish problem' is his problem and that he would resolve it through democracy (Yavuz 2009). But very little in the way of resolution was done in the following four years.

\footnotetext{
5 The European Union first listed the PKK as having 'been involved in terrorist acts' in 2002. It reaffirmed its position in 2011. Available at: http:/ / eur-lex.europa.eu/legalcontent/EN/TXT/?uri=OJ:L:2011:028:TOC [accessed 04.01.2015].
} 
In 2009, the AKP opened a public debate about a 'Kurdish opening'. After criticism from Turkish nationalists, including AKP members, this was renamed as a 'democratic opening'. Even this title was too radical for nationalist Turks, and the initiative was rebranded as 'the national unity and fraternity project.' Even though the Erdogan-led AKP had a dominant majority, it was difficult to even decide on a name for negotiations. However, Kurds and some Turks were still hopeful for peace.

Eventually, in late 2008 and the beginning of 2009, with the help of Norway and the United Kingdom, and for the first time in history, Turkish state representatives and the PKK, working alongside members of the Kurdish diaspora in Europe, had direct meetings and peace talks in Oslo. This is now called the Oslo Process. As in many other examples, including in Northern Ireland and South Africa, this process for preparation for peace was carried out secretly. According to many of my interviewees, there was even a signed declaration between Turkish state representative and the PKK about the peace process. However, this peace attempt could not be sustained. The Turkish government and the PKK each blamed the other for the collapse of the talks in 2011, after the minutes were leaked to the media, and the process was made public (Philips 2015). The broken promises and loss of hope after Oslo were followed again by some of the bloodiest conflicts between Turkish state forces and the PKK since before the 1999 Abdullah Ocalan arrest (Tezcur 2013). The Uludere massacre took place in December 2011, when 34 Kurdish civilians were killed by the Turkish air force (Economist 2012; Al-Monitor 2013; Goel 2015). This escalated the conflict. Following this, Ocalan's meetings with his lawyers and other visitors were cancelled. PKK prisoners in Turkey took part in lengthy hunger strikes at the end of 2012.

During this crisis I carried out fieldwork research in Germany. This included meeting and talking with Sakine Cansiz in Berlin, in December 2012. Cansiz was one of the founding members of the PKK and a prominent leader within the Kurdish women's movement. We discussed the conflict and the poor prospects for peace, just a few weeks before she and other two female Kurdish political activists were assassinated in Paris (9 January 2013). The murderer's links with the Turkish Intelligence Service (MIT) have been confirmed (Cumhuriyet 2015; Demir 2015). This tragic murder shows that Kurds are not just facing uncertainty and violence in their homeland, but they are also not safe in the diasporas, including in Western Europe.

Despite the bloody war, 67 days of hunger strike and the Paris assassinations, there was another step towards peace when Ocalan's ceasefire message was read during the Newroz 2013 celebrations in Diyarbakir. The PKK and Ocalan openly declared that 'peace process' negotiations were going on. This time 
the process was named the 'Imrali process', after the island where the imprisoned PKK leader, Ocalan, has been jailed since 1999. However, the Erdogan-led AKP government claimed for a long time that it was not the government but the state that was in contact with Ocalan and other Kurdish political representatives. This was an attempt to protect the AKP from any damage resulting from this process. They were avoiding the real issue, rather than taking any risks. As Candar (2015) states, the peace process in Turkey between Turks and Kurds was neither transparent nor mediated by a third party. The AKP government attempted to assert its strength by neglecting to include any independent parties, and this damaged the process' structural viability. Candar (2015) is clear that the "Kurdish issue has become an electioneering tactic on the part of the AKP and therefore any current peace process efforts would be lacking in substance and drive".

\section{Unbalanced 'peace processes'}

In 2009, the Turkish President Abdullah Gul acknowledged that the Kurdish issue was Turkey's most important problem. He claimed that "Good things are going to happen" (Turkone 2009; Lindenstrauss 2016). However, seven years after the 2009 Oslo talks and after 15 years of an AKP government there have still not been any substantive developments. Despite the talks between Ocalan and some key players, including some Kurdish MPs, the Turkish Intelligence Service and some AKP members, no 'good things' have happened. The current Turkish President Erdogan has been the unchallenged leader of both AKP and Turkey since 2002. He has consistently avoided, at least openly, either being part of the peace process or even working to move this process on. But even the basic right to use the Kurdish language is not yet legal. The Turkish constitution has not been changed to allow Kurds to use their language or have education in the Kurdish language (Tas 2014a; Aslan 2015). Abdullah Demirbas, the former Sur Mayor (Sur is a district in Diyarbakir) explained that staff in Kurdish municipalities, including elected Mayors like himself, have been prosecuted for speaking Kurdish. At the same time the AKP was promoting 'Kurdish Language' initiatives such as a staterun Kurdish TV channel, TRT6 (now TRT Kurdi), even those are still illegal under the constitution (Demirbas 2010). Ironically, the State is allowed to use Kurdish for its own political and assimilative aim, but Kurdish people and politicians are not allowed to use their own language.

Erdogan's primary agenda has been to promote his personal power, and restrict any challenges to it. This is why he was so keen to change Turkey from a parliamentary system to a presidency. This has always come before making peace. However, after Selahattin Demirtas, the co-leader of the proKurdish Peoples' Democratic Party, the HDP, declared in March 2015 that 
"we will not make you the president" (Hurriyet 2015), then Erdogan focused on playing the Turkish nationalist card. In April 2015, in direct contradiction of his 2005 Diyarbakir speech, he claimed that, "Turkey has no Kurdish problem". He has repeated this claim several times since 2015. The following months, he restarted the war against Kurds in Turkey and started a Syrian offensive.

When a peace process only involves a few of the parties to the conflict, and leaders are only concerned with their self-interest, it is not surprising that the results are as observed in the Turkish-Kurdish peace process. If peace negotiations are to be successful, and not rely solely on military action, the different parties must work together and be prepared to take risks to solve the dispute. Without a clear roadmap, a specified timetable, the involvement of all key stakeholders and interested third parties, plus international involvement, it is not possible to even start to resolve the differences between sides who have been in conflict for a long time. Neither key actors within different civil entities, nor all the various relevant political parties knew the details of negotiations between the imprisoned Kurdish leader and the AKP or state representatives. There was no clarity about the peace talks themselves, the possible reconciliation process, or possible new institutions in the formation of a potentially decentralised Turkish state. As we have seen in the Turkish-Kurdish case, empty promises in relation to this sort of socalled 'peace process' almost always open the door for brutal conflict. This is exactly what led to the conflict that started in June 2015.

Even if a peace process was successfully developing between the PKK and AKP then, in the long term, the exclusion of the other factions might well increase the possibilities of conflict. For example, Kurdish Hezbollah could turn their guns onto the Turkish state, saying that they do not recognise any peace process, and that they want to fight for an independent Kurdish or Islamic State. Similarly, Turkish nationalists (MHP, National Front Party), some Turkish leftish (including some members of the CHP, Republican People's Party) and former members of the Turkish military have not supported any moves towards peace processes with Kurds, including the most recent one. Instead, they have been championing more oppressive types of military operation in Kurdish regions (Yavuz and Ozcan 2007; Gocek 2011)

All previous negotiations were unbalanced. On one side of the imagined 'peace process' was the government of the Turkish state, on the other, an imprisoned leader under the control of that government and the state. Messages from Ocalan about the negotiations were delivered by a few selected Kurdish political party members. Research about peace and conflict suggests that, at the beginning, any peace process should be limited to only a 
few actors. ${ }^{6}$ But in the Kurdish and Turkish context there has been no substantive process over the last seven years. After all this time, we still do not even know whether there are any mutually agreed principles, and what they might be. There has not been an Observatory Committee. No Truth and Reconciliation Committee has been established until the day this research was completed. There has been no involvement from the UN or the European Union, or any other parts of the international community. Nor is it clear who might be the guarantor of any potential peace. Millions of people have suffered and have been forced to move to internal and external diasporas, as discussed above, because of the ongoing conflict.

Understandably, both the migrants and those people who have not moved have very little trust in the ongoing so-called peace process. All this makes both any talks and the overall peace process itself very fragile. The politics of the Middle East are extremely dynamic. Individual players and factions frequently swap allegiances (Rosenberg and Wolfsfeld 1977). It is therefore important that any peace process should include all main actors and factions (Laderach1997; Zartman 2007; Ramsbotham et al. 2011).

Kurds and Turks can only continue living together if there is a peaceful solution to the ongoing conflict. Even hope for peace cannot continue if promises keep being empty. Each new episode of violence acts as a reminder of the previous bad experiences and further increases hate between the different ethnic groups, making it more difficult for future generations to come together and make a durable peace. The recent wars with Kurds in Syria and Turkey will produce new developments, and may even challenge borders in the Middle East, including Turkey. Kurds have moved on from their old method of armed struggle against Turkey into societal resistance. They have named Turkey as a 'coloniser' or 'occupier' state. With the help of the transnational Kurdish diaspora, they have made the Kurdish issue into an international issue and so brought the Kurdish case to a similar level as the Israeli and Palestinian conflict, as discussed in more detail by Darweish and Rigby (2015).

\section{Diaspora and peace processes}

The underlying concern here is how to work towards successful negotiations for peace, including a stable post-conflict situation, with the help of Kurdish stateless diasporas. There is a large body of literature on diaspora, conflict and peace (see for example, Lederach 1997; Al-Ali 2007; Snyder 2015). One can easily observe deep differences between and within diasporic

\footnotetext{
${ }^{6}$ See for example: Rosenberg and Wolfsfeld 1977; Laderach1997; Wessels 1998; Zartman 2007; Harbom and Wallensteen 2008; Bercovitch 2009; Loizides 2009; Ramsbotham et al. 2011; Hamber 2015.
} 
communities. As in the Kurdish homelands, diaspora societies are not a unitary or homogenous entity. Religious and ideological divisions exist within Kurdish society. However they have also common political, cultural, geographical aims and wishes.

War and conflict over the past thirty years have forced hundreds of thousands of stateless Kurds to flee their homelands in Turkey and other countries in the Middle East in an attempt to secure safety outside of the region. Many of those who have moved to Western Europe experience continued feelings of alienation, with only limited feelings of belonging to their 'host countries', and a frequent sense of living in limbo. These sentiments have been an important engine of Kurdish nationalism, mobilising Kurdish men and women in the diaspora to bring an end to their perceived statelessness (Tas 2015 and 2016). The diaspora is seen by many as a safe environment within which to organise: creating not only 'long-distance nationalists' (Anderson 1998 and 2006; Sheffer 2002; Schiller et al. 2001; Schiller 2005) but also alternative institutions for a future, imagined state. It can be argued that statelessness, diaspora and nationalism are strongly connected in so far as statelessness and diaspora can be seen to feed nationalism. Since Kurds have no 'unitary' religious or linguistic identity, many Kurds have claimed that the only way forward is to become much more nationalistic. From this perspective, unity through nationalism is the only way to end Kurdish statelessness and to make a stable peace.

Many Kurds believe that Kurdish people, both as individuals and as a community, have not been 'strong enough' nationalists, since they have not been successful at establishing their own state. The weak nationalism of stateless people, including Kurds, has been part of academic debate in recent years. For example, Ismail Besikci, a well-known Turkish academic who has researched Kurdish issues for decades, has asserted that, "Kurds are not good enough nationalists. They should not be as democratic as they are today. It's too much. It is not Kurds' business to make Turkey a more democratic country" (Besikci 2014; Hamsici (2014).

Abdullah Ocalan, the imprisoned leader of the PKK, has also called on all Kurdish people around the world to unite, and to show resistance against their enemies (Letsch 2014). Kurds who have left the various imagined homelands of Kurdistan to live in diasporas, often take such calls for national solidarity especially seriously. The ISIS attack on Kobane (Rojova, North Syria), which has cost thousands of lives and caused suffering to hundreds of thousands of people, is the first time in history that Kurds from different parts of the world have joined together to fight for the same cause. These efforts demonstrate a significant shift in Kurdish nationalism: from localised and 
weak nationalism towards a collective, stronger form of nationalism with the help of diaspora mobilisation.

However, some other Kurds argue against stronger nationalism, and instead believe that Kurds need to be more democratic than they are currently. Abbas Vali, another well-known Kurdish academic, said: "I have to fundamentally disagree with Besikci. Kurds are not democratic enough" (Vali 2015). Kurds who want to promote a more advanced form of democracy are especially concerned about the rights of women and other powerless groups. They even want to champion the right to be heard for those people who hold political views in direct opposition to their own.

Because of long years under the assimilationist policies of the Turkish state, then until recently many Kurds have felt ashamed of their cultural identity. Many Kurds hid their Kurdishness and Kurdish roots (Tas 2014a). However, with the recent conflict in the Middle East and, especially, the victorious fighting in Kobane, more Kurds are now becoming increasingly proud of their Kurdishness. Linked to this, there is increasing Kurdish nationalism. As Kurds are still an underdog minority, this nationalism is developing into an 'aggressive' form which has been described by Bozarlan (2015) as 'narcissistic nationalism'7.

Members of the Kurdish diaspora have for many years tried to remove the Kurdistan Workers' Party (PKK) 8 from the European Union's list of designated terrorist groups (Channel Four News 2014). Freedom for Ocalan is another key goal of the Kurdish national diaspora movement. These movements are organised under the banner of the Kurdish National Congress in diasporas (KNC - Kongreya Neteweyî ya Kurdistanê). This was established on 24 May 1999, just a few months after Ocalan was arrested. Underlining the importance of the diaspora communities, the KNC is based in Brussels. This is a temporary arrangement which will last until Kurds have full independence, or at least, substantive autonomy.

Under the KNC banner, Kurdish transnational political and protest movements in Europe have made the world aware of the effects of ISIS attacks against Kurds in Shengal, Iraq and Kobane, Syria as well as Turkish state violence against Kurds in Turkey. I believe that Benedict Anderson (1998) is wrong when he claims that members of diaspora communities try to

\footnotetext{
7 The term was used first time by Sigmund Freud (1856-1939) appeared in his work "Civilization and Its Discontents (1929-30), in relation to the application of the inborn aggression in man to ethnic (and other) conflicts.

${ }^{8}$ The Kurdistan Workers' Party, Partiya Kărkeran Kurdistan (PKK) in Kurdish, began operations against the Turkish State in 1984. Since then more than 50,000 Kurdish and Turkish people have died as a result of the conflict.
} 
influence what is going on in their homeland without being physically involved in destructive conflicts. As part of my ethnographic research, I was told that thousands of young Kurdish men and women have travelled from London, Berlin or Istanbul to fight, and help the Kurds in Turkey and Syria. Some of these people are well-educated or work in well-paid professions. Even some of those who remained in their new host countries, or as internal migrants within Turkey, have been arrested for demonstrating their support for the Kurdish cause.

People from different diasporas who cannot go to fight themselves, instead organise fundraising events and take part in lobbying activities and demonstrations with the aim of persuading British and European politicians to help the Kurdish movements in Turkey, Iraq, Syria and Iran. For example, in September and October 2014, some London based Kurds even went on hunger strike for the Kurdish cause. Between June 2015 and March 2016, thousands of Kurds in different diasporas have carried out demonstrations and organised petitions against anti-Kurdish state operations by Turkey. Some of these Kurds have been criminalised by the British or Turkish state (Baser 2015; Garmiany 2015; Telgraf 2016).

Kurds are no longer just a local tribal group, operating through kinship networks. Kurdish lobbying in the diaspora may not be as strong as that for Turks, Armenians and Jews, but they are moving in that direction (Barzani 2014). Millions of Kurds and their supporters can, and do, take to the streets of Istanbul, Berlin, London, Paris, New York and Brussels, whenever there is an issue of serious concern. They also have increasingly strong and close relationships with the governments of their new host countries. For example, Kurds regularly use facilities within the UK parliament for meetings and political discussions, and several MPs and Lords usually input favourably. These increasing links should not be underestimated.

As we have seen, diaspora communities can easily become a driving engine for homeland politics, nationalist movements, and even armed conflict in the original homeland. They can also become an agent involved in putative peace processes. As discussed above, this was the case for the peace process between the PKK and Turkish state representatives, especially the Turkish National Intelligence Service. In 2009, initial negotiations were brokered with the help of diaspora representatives, in the so-called 'Oslo Process' (Tas 2015). This example demonstrates that the Kurdish stateless diaspora has already been an active, influential actor in policies affecting its homeland. One of my interviewees explained in November 2014 (Tas 2016):

If there is going to be [any] peace [with Turkey], it will be down to the diaspora. And that's true for conflict too. We are becoming as strong as the Armenian and Jewish 
diaspora. Assimilated Kurds in Turkey cannot make peace - or war - without us. We [diaspora Kurds] have suffered. And we [diaspora] will be a part oft he decisionmaking pricess, if there are going tob e any decision.

A Kurdish academic states in February 2016 that without 'true Kurds' at the peace table, it is not possible to make peace for Kurds. He describes what he means by 'true Kurds':

There are many false Kurds in Turkey and elsewhere. They have been assimilated under a host identity and can only think about their own personal needs, and the importance of their hosts. For example, the Turkish former presidents Ismet Inonu and Turgut Ozal, and other politicians who are involved in mainstream Turkish political parties, like AKP and CHP, might claim that they are from a Kurdish background. But for the whole of their political life, they have worked for the Turkish state. These sorts of people cannot and should not represent Kurds. Another group of false Kurds are those who try to make small changes to Turkish political structure, and so to claim a few minority rights for Kurds. They also don't represent Kurds. Ocalan himself can now be considered as falling into this group, since he has sacrificed the aim of Kurdish independence, for a few baubles. But I can forgive him because he is in Turkish prison. True Kurds are fighting for full Kurdish independence, or at very least, equivalent rights as the Turks have. Only these true Kurds deserve a place at the negotiation table.

This non-negotiable and hyper-nationalist view can be seen among many forcibly displaced stateless diasporas. Many people like this have very little trust in any so-called 'peace process'. All of this makes any talks and the peace process itself very fragile. Many of my interviewees do not trust the Turkish state, especially the Erdogan-led government, to make peace. Another of my interviewees explained in London, January 2015:

Of course we [diaspora Kurds] want peace. Who would not want peace? I have lived in three different diasporas in the last 30 years: In Germany, in France and now in the UK. I haven't seen my hometown or my relatives in Turkey since the 1980s. My land was occupied by the village guards. Peace may help people like me to end this misery and to have their land and their home back. But Turkey is not serious about making peace. Erdogan is just playing with us. He needs Kurdish votes and he has used us to stay in power since 2002. He has not made any legal changes in favour of Kurds in his last 13 years in power. He is not a friend of Kurds. We [Kurds] have to think beyond any national borders to help each other. We cannot trust others to help us to make peace; we should create our own state and pull down all the borders that divide us.

The imprisoned Kurdish leader, Ocalan, understands the potentially important role that diaspora communities have. He has repeatedly asked the diaspora to contribute to the development of the peace process both by organising discussions and other events, and also to involve European institutions and governments in these events. With this in mind, several conferences (May and December 2013, December 2014) were organised in Brussels by the KNC. 
At the 13 $3^{\text {th }}$ General Meeting of the KNC, held in Brussels on 25-26 May 2013, it was stated that Kurds have the right to live and create their own destiny in their own land as a Kurdish nation, and:

\begin{abstract}
Democratisation of [the] Middle East can be achieved through the recognition of Kurdish identity and Kurdistan as a nation... On these grounds Kirkuk and other parts of [the] Kurdish region[s] that were taken [by Turkey, Iraq, Syria and Iran] have to be included again in the map of Kurdistan, and these countries have to show their respect for the map of Kurdistan and its territory.
\end{abstract}

As we see from this explanation, there are no signs that Kurds, as represented by the PKK and KNC, have dropped their claim of creating a unitary Kurdish state. International law on self-determination also support such view (Thurer and Burri 2008). The Turkish President Recep Tayyip Erdogan has also pointed out in many speeches how various Kurdish power-holders, and especially diasporas, play a crucial role in the ongoing conflict and its resolution. The Kurdish diaspora is therefore recognised as an important influencing factor by both sides of the conflict.

\title{
Kurds are at last learning to play the system
}

More tactically, and perhaps more realistically, many Kurdish nationalists have temporarily postponed their aim to create a Kurdish state in Turkey, as they focus on state-making in Syria and Iraq. One Kurdish legal practitioner in Istanbul, who also functions as a Kurdish politician, said in November 2015:

Ironically, Kurds have to be thankful to Erdogan and the Turkish state's recent illconsidered internal and foreign policies against Kurds. These have shown the authoritarian face of Turkey to the world and the real extent of discrimination. This [might seem paradoxical, but it] has helped Kurds to increase their power. They now control a large area in Syria, and even control some cities in Turkey. Kurds are strengthening connections with various international powers and getting increasing Western support. So I want to see Erdogan in power a little longer. His aggressive policies may actually help Kurds to establish the independent state we have been dreaming for such a long time.

As long as the fight continues in Iraq, Syria and Turkey, the most radical Kurds can consolidate their increasingly radical members around that struggle. As Jok says for the South Sudanese case: "nations don't just happen - they have to be planned, forged and crafted" (Jok 2012). Many Kurds are aware that the processes and techniques for state making are not easy and may take a long time. For example, the Mayor of Kobani acknowledged that, "we [Kurds] are not professional [yet] when it comes to independence" (Abdi 2015). Cemil Bayık, one of the founders and leaders of the outlawed PKK, has said that: 
When the chaos that is engulfing the Middle East is taken into consideration, disarming is not possible... Ankara should change its stance against the Kurds... Turkey should develop peaceful political and economic relations [with Kurds]... Direct communications should be established between Ocalan [imprisoned PKK leader Abdullah] and Kandil [the mountains where the PKK militants are based]. And finally, the negotiations should officially be launched. If all these conditions are applied, then our arms might be silenced (Today's Zaman 2015).

Kurds in Syria and Turkey are slowly but surely developing their relations with the rest of the world. The French President Francois Hollande had a meeting with two senior PYD women, Asya Abdullah (the co-chair of the PYD) and Nesrin Abdullah (the commander of YPG's female branch) on 8 February 2014. There are now YPG flags on the doors and walls of the European Parliament and Kurdish officials now have offices across Europe. Kurds are welcomed by the Russian government and opened an office in Moscow in the name of the Rojova administration. (Tastekin 2016).

Many of my interviewees believe that the sort of democratic autonomous system that Ocalan and many Kurdish nationalists currently support for Turkey would not only give time but would also allow some of the necessary preparations for a future unitary Kurdish state. Kurds already practice their own legal system de facto for business, family and even criminal cases as part of their practical resistance against the Turkish state and institutions of the state. This is also an integral part of the Kurdish state building project, which has been re-developed and introduced by the Kurdish people wherever they live, including the UK and German diasporas (Tas 2013a, 2013b and 2014a).

\section{A Case from the Kurdish Court}

As an example of this, I would like to discuss a legal case that I observed during my previous fieldwork in the UK with the Kurdish unofficial court there, the Kurdish Peace Committee. Similar Kurdish legal practices are carried out on a daily basis by Kurdish elected or voluntary community judges in Kurdish towns and cities in Turkey.

A Turkish Businessman in the Kurdish Court 9 , as an example of how diaspora can create alternative institutions and act to solve their legal problems (Tas 2014a). In this case a Turkish man had a joint business with another Turk. The two men wanted to end their partnership and one of the partners, Katip, asked for his financial input of $£ 30,000$ to be returned to him; Suleyman, the other partner, refused. Katip did not want to go to an official court because the partners had no written agreement. He also did not want to risk losing

\footnotetext{
${ }^{9}$ This case has also been discussed in Tas (2014). All the names of case participants are pseudonyms. The information for this case is based on the plaintiff's statement to the KPC; my observation of the KPC meeting over this case and an interview with Katip and his son, interviews November 2010.
} 
any more money in a court case. His son advised him to take the issue to the Kurdish Peace Committee (KPC). But the father refused, saying, "instead of taking my case to the KPC and paying them a huge sum, Suleyman can keep the money." He reasoned: "this is a Kurdish organisation and must have a connection with the PKK. I am not going to ask the PKK to help me. If I give my arm to them, they will take my whole body." However, his son insisted, saying, "Please, let's try. We won't lose anything if we try. If they have any secret agenda, we will come away, I promise you."

In the end the father listened to his son. He took his case to the KPC on 1 November 2010. They followed the usual procedure: filling in a short form and paying a fee of ten pounds. The following week, on 8 November 2010, both sides, the plaintiff and the defendant, came to the KPC for the meeting.

Usually a leading KPC member makes an opening speech before a case begins. Especially if the judges do not know the parties involved, they might start by exploring the background; asking who the parties are, where they are from, what kind of business they have and who they know within the Kurdish community. Depending on the answers, they may ask how they heard about the work of the KPC. After getting to know the parties a little, they usually remind them of the rules and procedures, telling them that both sides will be given time and space to speak but that they should not use any violence or harsh words on each other. Last, but not least, they ask if both parties are happy to be at the KPC and if they are ready to follow and accept any decision the Committee might make. A similar introduction is made before all cases. If the judges already know the parties well, they keep it short; if they are less well known, the judges will ensure that both parties fully understand the system. After this introduction, as with all cases, both parties explained their position. After only around 30 minutes, the KPC decided that Suleyman must return the $£ 30,000$, through the KPC.

Both sides agreed to this decision, and Suleyman wrote out a cheque. Katip was shocked and surprised, and then asked the KPC members: "how much must I pay you for this help?" The senior KPC judge answered, "You have already paid your ten pound fee. You do not have to pay anything more. We are not working for money." Katip was still confused and then offered $£ 2,000$ towards community work. The KPC asked Katip several times if he was sure that he wanted to donate money, because he was not obliged to do this. Katip insisted, so, after some hesitation, the KPC accepted the donation. Some people who have reached an agreement offer money in this way, especially after a business conflict. The amount is not fixed and is never asked for. Any donated money is usually used to help teach Kurdish; to help members of the community who are in need; to help run different community works; to buy 
books or newspapers for the community; to organise meetings, seminars or conferences; or send to Kurdish regions if some members of the community are in need. Some of my Kurdish and Turkish interviewees stated that some of this money is spent on Kurdish guerrilla movements.

Similar to the introduction in each case, there is usually a closing speech from a senior judge. Normally this includes the importance of people respecting each other, helping each other and being honourable (namuslu) men and women in the community. The judges usually remind the parties that they have made a promise 'on their honour' (namus), and that they should never forget this promise. After this, the case is closed, the parties leave and the next case begins.

After that, Katip left the meeting room, and re-joined his son in the main community building. Katip told his son how surprised he was and added: "if a similar problem ever happens again, I know where to go." His son replied: "I told you that they find solutions very quickly, and that people listen to them. People even come from Turkey and Germany to use the KPC."

In this case, neither of the parties was Kurdish but enforcement was still based on maintaining good social relationships. Furthermore, this type of alternative Kurdish community action shows that Kurds in diaspora are redeveloping their legal institutions for their own people and also as part of the preparation of a future autonomous or independent Kurdish state.

This case has clearly illustrated that not just Kurdish people, but also many Turkish people, are not happy with the structure and work of centralised state institutions. Community centres, the offices of Kurdish mayors in Turkey, and mosques in Turkey and also in diasporas have acted as a place for many people looking for solutions to their disputes, when they don't want use state institutions. The fact that many Turks are also using Kurdish courts both in diasporas and also in Turkey, when they are looking for 'justice', is important evidence that the relationship between Turks and Kurds is not totally broken and still can be repaired. These alternative de facto institutions, their work and the connections between two communities, can play a positive role in the development of any sustainable peace. These institutions can also play a role in cultural or societal reconciliation, democratisation and decentralisation of state institutions.

\section{Concluding remarks and 15 steps for sustainable peace}

Previous peace negotiations between Turks and Kurds have never been balanced. Messages from Ocalan about any negotiations are carried only by a few selected Kurdish political party members. Although any peace process 
must necessarily be limited initially with only a few actors, as we saw in Northern Ireland and South Africa, there seems to have been no substantive progress over the last three decades. Many important Kurdish and Turkish entities, including the diasporas, have never been included in any substantive way. Diaspora, for stateless people, is not only a place outside of their country of origin, but can include their ancestral village or city, when insecurity and inequality continue there.

Kurdish diaspora communities are the result of, and key actors in, the conflict. They have acted not only as an important driving engine for homeland politics, but also as a way forward to peace and to the development of future Kurdish institutions. Some elements in Kurdish diasporas have recently promoted a strong and even aggressive nationalism. These contradictions may be an important barrier for Kurdish leaders to overcome if there is ever going to be peace with Turkey and neighbouring states.

Turkey, since its establishment as a Republic, has never achieved sustainable peace. Kurds still cannot freely learn and use their language in educational, legal, political and even social arenas. The PKK movement and the conflict between Turks and Kurds is one of the major reasons for this. The Turkish state has not tried to make peace in any real way, merely reiterated attempts at military 'solutions'. These have not brought about any progress in the last hundred years, and are not moving anything forward now. Different Turkish governments have mouthed platitudes and postponed any real actions towards peace. There has never been any substantial move towards building trust and increasing tolerance between and within different ethnic groups. Successive Turkish governments did not show any understanding of the real sociological problems in Turkey.

The PKK benefits from pre-existing problems of the Kurds and does not find it difficult to recruit new members. Thousands of young people join the PKK voluntarily every year (Letsch 2006b). This shows that as long as the current conflict continues, the PKK or similar organisations will not only exist but will thrive. New groups, such as the TAK or other Young Kurdish militias within towns and cities, are now more radical than the PKK (Kuntz et al. 2016).

Kurds, with the help of their international connections, may be making real friends for the first time. USA and Russia's support of Kurds in Syria (YPG, the Kurdish People's Protection Units) has increased Turkey's aggression against the Kurds. The development of Kurdish autonomy in Syria and HDP's success in Turkey have awakened Turkey's historic fear of the state's division and the unification of Kurdish lands with those in neighbouring 
countries. For this reason all Turkish political elements (secularist, Islamist and nationalist) have joined forces against the Kurds.

Especially Erdogan has used this monopoly of power for his own use. Erdogan's eagerness to stay in power has moved Turkey towards an authoritarian regime in which freedom of expression and rule of law have already deteriorated. The Erdogan-led regime seems to have a zero respect for the rule of law if its requests or orders are not supported. Erdogan even spoke about removing the constitutional court because that court wanted to release two journalists who were arrested on his orders (Beale 2016; Ellis 2016; New York Times 2016; The Guardian 2016a; The Washington Post 2016). He has used the refugee card as a bargaining chip with the EU to promote his own power (Pitel 2016b).

He has even expanded the meaning of terrorism and suggests removing citizenship from the so-called 'supporters' of terrorism, including journalists or academics who signed the petition for peace between Turks and Kurds (Reuters 2016; Zalewski 2016). He has undermined even the implementation of 1980s military made, monolithic and centralised constitution in many ways. It therefore seems very unlikely that any Erdogan-led government might develop a constitution which could move forward many of the issues plaguing Turkey, let alone the Turkish-Kurdish conflict.

Any critical media has been taken under state control. Even social media, like Facebook and Twitter, have been switched on and off at government will. Critical voices, especially pro-Kurdish journalists, have been arrested. As of April 2016, almost 40 journalists and tens of lawyers are in prison. Hundreds of academics who, in January 2016, signed a peace petition against state oppression and operations against the Kurds have faced disciplinary actions. Many of them have been put in pre-trial detention, and are facing several years in prison, on the personal orders of Erdogan. Erdogan has been eliminating all opposition ahead of his bid for an executive or Sultan style of presidency, and he regards the Kurds as the main barrier to achieving this.

Many Kurds I have interviewed in Diyarbakir, Istanbul, Berlin and London are angry with both the Erdogan-led AKP goverment's brutal response to Kurds and also with the PKK for taking the fight to the towns and cities and moving away from any peace talks.

The question of what the Kurds want has been asked by many politicians, international organisations, journalists and academics. First of all, it is important to acknowledge that Kurds, like many other communties and nations, do not speak with one voice. Even the PKK has diverse voices, including Kandil, Ocalan, the Young Kurds, or youth militia and diasporas. 
There is also a wide range of other Kurds, including Alevi Kurds, women's rights organisations, HDP and youth organisations and conservative religious Kurds. All these sub groups may well contradict each other. Looking at the bigger picture, when south Kurdistan (KRG), East Kurdistan (Iran), Rojova (Syria) and North Kurdistan (Turkey) are included, the diversity increases. One of my interviewees commented: “Kurds do not need any more enemies, they have themselves. They are a nation with many armies and divisions."

Many Turkish or western academics, journalists and diplomats use this heterogeneity and the lack of a single representative as an excuse not to negotiate with Kurds. They have suggested that Kurds cannot be a nation. But Turks, Britons and Germans are similarly heterogenous. Just like Turks, Britons, Germans and all other nations, Kurds have some common issues and wishes, and representatives who will argue for these.

\section{5 important steps towards sustainable peace}

This article has already discussed why the previous peace negotiations have failed. Looking forward towards possible solutions for a 'one state solution', I contend that there are 15 important steps which must be fulfilled for sustainable peace.

First, the Turkish state and the PKK should declare a ceasefire for at least one year. This would create the necessary conditions for peace talks to begin.

Second, international involvement and guarantees are essential. The European Union and United States must put pressure on the Turkish government to promote peace and also to equalise unequal conditions among stakeholders for the peace table. There is an international historical context, with effects on international stability and important human rights issues to consider. These all mean that there is a wide international responsibility to observe, oversee, and to take an active part in facilitating the peace process.

Third, the Kurdish leader in Turkey, Abdullah Ocalan should be released from prison. This is a necessary pre-condition before any real peace process can begin. Only free and equal people can talk and make peace.

Fourth, any peace talks should be inclusive and involve all key stakeholders. Not only the AKP and PKK, but other important Kurdish and Turkish stakeholders, especially women's groups, should take part in the peace discussions. With Kurdish populations living in their historical regions in Syria, Iraq, Iran and Turkey, as well as in the diasporas, one cannot separate the Kurdish and Turkish 'peace process' from ongoing conflicts and wars in 
the neighbouring countries. Many of the Kurds I interviewed believe that for any successful and permanent peace, Kurds living in all of these places, including the diasporas, must be involved in the peace process.

Fifth, the objectives of the peace process should be clearly defined. Each step should be accepted, with time frames agreed by all sides.

Sixth, independent justice, the disarmament of Kurdish fighters, and a reconciliation process with amnesty for all political prisoners, must be implemented if any peace process and subsequent coexistence is to be successful in the long term.

Seventh, as in many other societies with a history of conflict, Turkey needs a new, more inclusive constitution if it is to move away from the existing problems. The country is still using the constitution created by the military after the 1980 coup. The new constitution and any amendments affecting its Basic Rights and Turkey's ethnic communities cannot be approved without a qualified majority of two-thirds of votes, within which there must be a majority of votes from the Kurdish community. This should hopefully protect the constitution from any majoritarian or authoritarian ruler in the future.

Eighth, the existence and distinct identity of Turkey's different ethnic and religious groups such as the Kurds should be recognised and protected in the new constitution's basic rights. The concepts of one religion, one nation, or brotherhood cannot keep Turks, Kurds and any other groups together if there is no tolerance of differences. Without tolerance, the idea of one umbrella identity can only be a temporary solution, and will not resolve the TurkishKurdish problems that have been observed for a century. Pluralistic society is a fact and one person should not be forced to wear someone else's hat. Any peaceful society requires tolerance and respect. As Adorno (1991) and also Laclau and Mouffe (1985) have emphasised, the appreciation of diversity means to be diverse without being frightened, and to respect and tolerate the value of others.

Ninth, respect for the rule of law and democratic values, freedom of speech, freedom of the media, the promotion of gender, ethnic and religious equality at all levels, and decentralisation should be part of the basic rights included in any new constitution. The new constitution should also include a way for Kurds and other minority groups to be part of truly democratic politics. This means that the removal of the current 10 percent parliamentary threshold is necessary.

Tenth, devolution or federalism can contribute to a resolution of almost one hundred years of the Turkish-Kurdish conflict, since the unitary and 
centralist system has been a significant contributor to the conflict. The new constitution should decentralise power down to elected co-mayors in the towns and cities, rather than to centrally-appointed governors. Kurds have already successfully introduced and practice a system of co-mayors and cochairs that promotes gender equality. Political, administrative and fiscal decentralisation, with the creation of local police forces would contribute to a new, peaceful and pluralistic one-state solution for Turks and Kurds. Education, healthcare, economic development and sport activities should be decentralised. The constitution should also permit the use of Kurdish as a working language in areas where the Kurds form the majority. Such multilingual practices have already been practised successfully in South Tyrol (Italy), Catalan and Basque regions (Spain) and Quebec (Canada).

Eleventh, various consociational power-sharing principles advocated by Arend Lijphart should be reflected in the new constitution (Lijphart 1977 and 2008). Examples should include the future formation of coalition governments which represents all major segments of the divided society, including the Kurds; proportionality in legislative and executive bodies such as the the Constitutional Court, and within the public administration and allocation of public funds; minority veto rights on all essential decisions and the existence of arbitration mechanisms.

Twelfth, a new pluralistic and inclusive state should include full education in the Kurdish language. Primary through to university level education should be state funded, as it is in the Republic of Macedonia where education in the Albanian language is available at all levels (Lyon 2016). South Tyrol (Italy), Catalan and Basque regions (Spain) and Quebec (Canada) are just a few other important successful examples.

Thirteenth, use of community flags and symbols should be allowed in areas where minority groups form the majority. In the long term it may be necessary to create a new, inclusive state flag for all as was the case in South Africa.

Fourteenth, economic development in the Kurdish areas is one of the most important steps for ensuring sustainable peace. The long-term conflict has created social and economic inequalities, which fuel yet further conflict. There should be an aim to remove social and economic inequalities between different parts of Turkey. This might require, for a limited period of time, positive discrimination in Kurdish areas.

Fifteenth, the substantial post-conflict ecological and environmental damage in Kurdish areas should be repaired according to local historical and cultural 
values. The replacement of forests and sustainable local water resources is just as important as the renovation of historical monuments.

Political and constitutional changes need to be adopted, appreciated and practiced not only by the state, but across society. All these elements underline how peace could be managed in conflicted societies.

Especially during the past two decades, many of the nation states that rejected plurality have faced civil war and, usually, division. The former Yugoslavia, Iraq, Syria and Sudan are just a few examples. Many more accommodating countries have accepted, respected and made space for their ethnic diversity. As discussed in more detail in Tas (2014b), with the help of the Millet Practice, the Ottoman Empire managed to keep together its very diverse society for more than five centuries. Switzerland has successfully managed its diversity under a confederal system since 1815. The Scots, Welsh and Northern Irish have their own devolved administrations in the UK. Germany has sixteen federal states. Spain is increasingly making space for Catalan and Basque power. Macedonia has avoided civil war by enshrining in its constitution a decentralised model of governance (Lyon 2016).

Kurds have already established some de facto institutions during the ongoing conflict. The current, centralistic, authoritarian state position of Turkey may not be able to persist for much longer. If the state breaks down any further, Turkey will be left in as brutal a situation as Yugoslavia, Iraq, Sudan and Syria. And Europe will have an even larger flood of incoming refugees.

\section{References}

Abdi, Mustafa (2015) External threats: the example of Kobane. The Congress of Local and Regional Authorities of the Council of Europe, Strasbourg, 25 March 2015.

Adorno, Theodor (1991) The Culture Industry: Selected Essays on Mass Culture. London: Routledge.

Akbaba, Yunus (2014) “6-7 Ekim Olayları” ve Çözüm Süreci. Siyaset, Ekonomi ve Toplum Arastirmalari Merkezi (SETA), 78, [Online, 23.10.2014]. Available at: http:// setav.org/tr/6-7-ekim-olaylari-ve-cozum-sureci/perspektif/17648 and http://file.setav.org/Files/Pdf/20141022190303_"6-7-ekim-olaylari"ve-cozum-sureci-pdf.pdf [accessed: 07.04.2016].

Al-Ali, Nadje (2007) Gender, Diasporas and Post-War Conflict. In Hazel Smith and Paul Stares (eds.) Diasporas in Conflict: Peace-Makers or PeaceWreckers? Tokyo, New York \& Paris: United Nations University Press, 39-62. 
Al-Monitor (2013) Turkey's Kurds want explanation, apology for Roboski massacre. Al-Monitor [Online, 28 December 2013]. Available at: http://www.al-monitor.com/pulse/originals/2013/12/turkish-kurdsremain-estranged.html\# [accessed: 01.02.2016].

Amnesty International (2016a) Turkey: Indefinite 24-hour curfew, over 200,000 in danger. Amnesty International Website [Online, 11 January 2016]. Available at: https://www.amnesty.org/en/documents/EUR44/3178/2016/en/ [accessed: 24.01.2016].

Amnesty International (2016b) Turkey: Onslaught on Kurdish areas putting tens of thousands of lives at risk.' Amnesty International website [Online, 21 January 2016]. Available at: https://www.amnesty.org/en/latest/news/2016/01/turkey-onslaught-onkurdish-areas-putting-tens-of-thousands-of-lives-at-risk/ [accessed: 24.01.2016].

Anderson, Benedict (ed.) (1998) The Spectre of Comparisons, Nationalism, Southeast Asia, and the World. London, New York: Verso.

Anderson, Benedict (2006) Imagined Communities: Reflections on the Origin and Spread of Nationalism. London, New York: Verso.

Aslan, Senem (2015) Nation-Building in Turkey and Morocco: Governing Kurdish and Berber Dissent. New York: Cambridge University Press.

Barzani, Niyaz (2014) Kurdish Diplomacy: A Success Story. Rudaw [Online, 11 August 2014]. Available at: http://rudaw.net/english/opinion/11082014 [accessed: 21.11.2015].

Baser, Bahar (2015b) Turkish-Kurdish conflict spills over into Europe. The Conversation [Online, 16 October 2015]. Available at: http:// theconversation.com/turkish-kurdish-conflict-spills-over-intoeurope-47610 [accessed: 25.01.2016].

BBC News (2016a) Af Orgutu: Guneydogu'daki operasyonlar toplu cezalandirmaya benziyor. BBC Turkish News [Online, 21 January 2016]. Available at: http://www.bbc.com/turkce/haberler/2016/01/160121_amnesty_turkiye? ocid=socialflow_facebook [accessed: 25.01.2016].

BBC News (2016b) Syria: the story of the conflict. BBC News [Online, 3 February 2016]. Available at: http://www.bbc.co.uk/news/world-middleeast-26116868 [accessed: 15.02.2016]. 
Beale, Charlotte (2016) Turkish President Erdogan threatens court's 'existence' after it releases two journalists. Independent [Online, 12 March 2016].

Available at: http://www.independent.co.uk/news/world/europe/erdogan-threatenscourts-existence-after-it-releases-two-journalists-a6927421.html [accessed: 04.04.2016].

Bercovitch, Jacob (2009) Mediation and Conflict Resolution. In Jacob Bercovitch, Victor Kremenyuk and William Zartman (eds.) Sage Handbook of Conflict Resolution. London: Sage, 340-354.

Besikci, Ismail (2014) Presentation at the Public Forum: The Crisis of Middle East and Kurdish Question, Organised by the Centre for Turkey Studies (CEFTUS) in the House of Commons, 07.04.2014.

Bozarslan, Hamid (2015) Presentation at the conference: Rediscovering The Kurds in the Middle East: New Developments and Prospects. Organised by the London Middle East Institute, SOAS, University of London [Online, 24 April 2015]. Available at: https://www.soas.ac.uk/lmei/events/24apr2015-thekurds-in-the-middle-east-new-developments-and-prospects.html [accessed 07.05.2015].

Cakan, Seyhmus (2015) Erdogan Says Turkey to Annihilate Kurdish Militants, 25 Killed. Reuters [Online, 17 December 2015]. Available at: http://www.reuters.com/article/us-turkey-kurdsidUSKBN0U01B920151217 [accessed: 25.01.2016].

Candar, Cengiz (2015) Presentation at the Westminster debate 'Kurdish Issue: Is Peace Still on the Table?' Organised by the Centre for Turkish Studies (CEFTUS), UK [Online, 27 October 2015]. Available at: http://ceftus.org/2015/10/31/ceftus-westminster-debate-kurdish-issue-ispeace-still-on-the-table/ [accessed: 02.02.2016].

CBC (2016) Despite ISIS attacks, Turkey focused on 'the Kurdish problem. CBC News [Online, 20 January 2016]. Available at: http://www.cbc.ca/news/world/turkey-isis-kurds-1.3408372 [accessed: 18.02.2016].

Channel Four News (2014) Kurds in UK say; "Decriminalise the PKK!" The UK Channel Four News [Online, 9 September 2016]. Available at: http://www.you2repeat.com/watch/?v=MS5i_Swqj_8 [accessed: 24.01.2016].

Cohen, Robin (1997) Global Diasporas: An Introduction. London: UCL P. 
Connor, Walker (1986) The Impact of Homelands upon Diasporas. In Gabriel Sheffer (ed.), Modern Diasporas in International Politics. New York: St. Martin's, 1986, pp. 16-46.

Cumhuriyet (2015) Hakan Fidan, 'Paris suikastını MiT'teki bir grup yaptı' dedi. Cumhuriyet [Online, 14 March 2015]. Available at: http://www.cumhuriyet.com.tr/haber/turkiye/231251/Hakan_Fidan_P aris_suikastini_MiT_teki_bir_grup_yapti_dedi.html [accessed: 25.01.2016].

Cumhuriyet (2016) 'Türkiye' deki halkın yüzde 30'u başka bir ülke vatandaşı olmakistiyor.' Cumhuriyet [Online, 16 February 2016]. Available at: http://www.cumhuriyet.com.tr/haber/turkiye/482163/Turkiye_deki_halk in_yuzde_30_u_baska_bir_ulke_vatandasi_olmak_istiyor.html\# [accessed: 18.02.2016].

Daglar, Ali (2014) 6-7 Ekim'in acı bilançosu 50 ölü. Hurriyet [Online, 6.11.2014]. Available at: http://www.hurriyet.com.tr/gundem/27525777.asp [accessed: 14.04.2015].

Darweish, Marwan and Andrew Rigby. 2015. Popular Protest in Palestine: The Uncertain Future of Unarmed Resistance. Pluto Press.

Demir, Emre (2015) Le Monde publishes indictment claiming MIT involved in Paris murder of 3 PKK women. Today's Zaman [Online, 24 July 2015]. Available at: http://www.todayszaman.com/anasayfa_le-mondepublishes-indictment-claiming-mi-t-involved-in-paris-murder-of-3-pkkwomen_394493.html [accessed: 25.01.2016].

Demirbas, Abdullah (2010) Abdullah Demirbas Interview Part 1 and Part II. FreeKurdishMayors's channel and also YouTube [Online, 8 January 2010. Available at: https://www.youtube.com/channel/UCbjAjV_dK3dk5ol2Bgtd9kw [accessed: 24 October 2015].

Dogan, Yonca Poyraz (2016) Çandar: Turkey might be torn apart if current Kurdish policy continues. Today's Zaman [Online, 4 October 2011]. Available at: http:// mobile.todayszaman.com/monday-talk_candar-turkey-might-betorn-apart-if-current-kurdish-policy-continues_400600.html\# [accessed: 24.01.2016].

Economist (2012) The Kurds and Turkey: Massacre at Uludere. Economist [Online, 9 January 2012]. Available at: http://www.economist.com/node/21556616 [accessed: 01.02.2016]. 
Ellis, Robert (2016) Turkey has become a rogue state - and even Erdogan must face up to the fact. Independent [Online, 3 March 2016]. Available at: http://www.independent.co.uk/voices/turkey-has-become-a-rogue-stateand-even-erdogan-must-face-up-to-the-fact-a6909196.html [accessed: 04.04.2016].

Ensaroglu, Yilmaz (2013) Turkey's Kurdish Question and the Peace Process. Insight Turkey, 15(2): 7-17.

Garmiany, Polla (2015) Politicians, protesters in Germany condemn Turkey attacks on PKK. Rudaw [Online, 26 July 2015]. Available at: http://rudaw.net/english/middleeast/turkey/260720153 [accessed: 25.01.2016].

Geerdink, Frederike (2014) Kurds who became 'Village Guards' and fought PKK rebels in Turkey to be disbanded - but fear a betrayal. Independent [Online, 16 February 2014]. Available at: http://www.independent.co.uk/news/world/europe/kurds-who-becamevillage-guards-and-fought-pkk-rebels-in-turkey-to-be-disbanded-but-theyfear-a-9131095.html [accessed: 15.02.2016].

Geerding, Frederike (2016) Kurdish lawyers in Turkey - 'It's a reality that my life is in danger'. Beaconreader [Online, 6 April 2016]. Available at: https://www.beaconreader.com/frederike-geerdink/kurdish-lawyers-inturkey-its-a-reality-that-my-life-is-in-danger\#.VwUzRZqR5SI.twitter [accessed: 17.04.2016]

Gocek, Fatma Muge (2011) The Transformation of Turkey: Redefining state and society from the Ottoman Empire to Modern Era. London. New York: I.B. Tauris.

Goel, Taylor (2015) Three years after Roboski massacre in Turkey, justice is yet to be served. Liberation [Online, 1 January 2015]. Available at: https://www.liberationnews.org/three-years-after-roboski-massacre-inturkey-justice-is-yet-to-be-served/ [accessed: 01.02.2015].

Hamber, Brandon (2015) Dealing with Painful Memories and Violent Pasts Towards a Framework for Contextual Understanding. Berghof Foundation, Handbook Dialogue Series No. 11. Available at: http://www.berghoffoundation.org/fileadmin/redaktion/Publications/Handbook/Dialogue_C hapters/dialogue11_hamber_lead.pdf [accessed: 16.02.2016].

Hamsici, Mahmut (2014) Ismail Besikci: Kurtler Milliyetci Olmalidir. BBC Turkish Service [Online, 9 April 2014]. Available at: 
http://www.bbc.com/turkce/haberler/2014/04/140409_ismail_besikci_ro portaj [accessed: 18.11.2015].

Harbom, Lotta and Peter Wallensteen (2008) Dyadic Dimensions of Armed Conflict, 1946-2007. Journal of Peace Research, 45(5), pp.697-710.

Hurriyet (2015) We will not make you the president, HDP co-chair tells Erdoğan. Hurriyet Daily News [Online, 17 March 2015]. Available at: http:/ / www.hurriyetdailynews.com/Default.aspx?pageID=238\&nID=7979 2\&NewsCatID=338 [accessed: 29.01.2016].

ICG Report (2016) The Human Cost of the PKK Conflict in Turkey: The Case of Sur. International Crisis Group (ICG) [Online, 17 March 2016]. Available at: http://www.crisisgroup.org/en/regions/europe/turkey-

cyprus/turkey/b080-the-human-cost-of-the-pkk-conflict-in-turkey-the-caseof-sur.aspx [Accessed: 15.04.2016].

Ignatius, David (2016) The growing risk of civil war in Turkey. The Washington Post [Online, 3 March 2016]. Available at: https://www.washingtonpost.com/blogs/postpartisan/wp/2016/03/03/the-growing-risk-of-civil-war-in-turkey/ [accessed: 16.04.2016].

Jok, Madut (2012) Sudan after Separation - New Approaches to a New Region. South Sudan: Building a Diverse Nation, edited by Heinrich Böll Foundation and Toni Weis. Publication Series on Democracy, volume 28. Berlin, Germany: Heinrich-Boll-Stiftung: 58-67.

Karaca, Ekin (2016) 6 Saldırı, 234 Ölü, Bir Görevden Alma, Sıfır İstifa. Bianet [Online, 18 February 2016]. Available at: http:// m.bianet.org/bianet/ siyaset/172243-6-saldiri-234-olu-bir-gorevdenalma-sifir-istifa [accessed: 18.02.2016].

Kuntz, Katrin, Onur Burcak Belli and Emin Oezmen (2016) Children of the PKK: The Growing Intensity of Turkey's Civil War. Spiegel [Online, 12 February 2016]. Available at: http://www.spiegel.de/international/world/escalating-turkish-civil-warsees-young-fighters-on-front-a-

1076663.html\#spRedirectedFrom=www\&referrrer=http:/ / m.facebook.com [accessed: 17.04.2016.

Laclau, Ernesto and Chantel Mouffe (2001) Hegemony and Socialist Strategy: Towards a Radical Democratic Politics. Second Edition, London and New York: Verso. 
Lederach, John Paul (1997) Building Peace: Sustainable Reconciliation in Divided Societies. New York: United States Institute of Peace.

Letsch, Constanze (2014) 'Their fight is our fight': Kurds rush from across Turkey to defend Kobani. The Guardian [Online, 26 September 2014]. Available at: http://www.theguardian.com/world/2014/sep/26/kurdsrush-across-turkey-defend-kobani-isis-syria [accessed: 24.03.2015].

Letsch, Constanze (2016a) Turkey says Kurds in Syria responsible for Ankara car bomb. The Guardian [Online, 18 February 2016]. Available at: http://www.theguardian.com/world/2016/feb/18/explosion-hitsanother-turkish-military-convoy-one-day-after-ankara-attack [accessed: 18.02.2016].

Letsch, Constanze (2016b) In a devastated Turkish town, teenagers dream of joining the Kurdish guerrillas. The Guardian [Online, 3 April 2016]. Available at: http://www.theguardian.com/world/2016/apr/03/diyarbakirkurdish-teenagers-dream-of-becoming-guerrillas?CMP=share_btn_fb [accessed: 16.04.2016].

Lijphart, Arend (1977) Democracy in Plural Societies: A Comparative Exploration. London: Yale University Press.

Lijphart, Arend (2008) Thinking About Democracy: Power Sharing and Majority Rule in Theory and Practice. Abingdon: Routledge.

Lindenstrauss, Gallia (2016) Back to Square One? The Collapse oft he Peace Process with the Kurds in Turkey. Strategic Assessment, 18(4), 97-106.

Loizides, Neophytos G (2009) Elite Framing and Conflict Transformation in Turkey. Parliamentary Affairs, 62(2): 278-297.

Lyon, Aisling (2016) Decentralisation and the Management of Ethnic Conflict: Lessons from the Rebublic of Macedonia. Abingdon: Routledge.

Marcus, George (1995) Ethnography in/of the World System: The Emergence of Multi-sited Ethnography. Annual Review of Anthropology, 24: 95-117.

New York Times (2016) Democracy's Disintegration in Turkey. New York Times [Online, 7 March 2016]. Available at: http://www.nytimes.com/2016/03/08/opinion/democracysdisintegration-in-turkey.html [accessed: 21.03.2016].

Palmer, Colin (1998) Defining and Studying the Modern African Diaspora. Perspectives, 36. 
Philips, David L. (2015) The Kurdish Spring: A New Map of the Middle East. New Brunswick: Transaction Publishers.

Pitel, Laura (2016a) Turkey in crisis: Renewal of conflict with Kurdish militants is accompanied by a highly toxic political and media climate. Independent [Online, 19 January 2016]. Available at: http://www.independent.co.uk/news/world/middle-east/turkey-incrisis-renewal-of-conflict-with-kurdish-militants-is-accompanied-by-ahighly-toxic-a6821941.html [accessed: 24.01.2016].

Pitel, Laura (2016b) British academic deported from Turkey after 25 years over 'terror propaganda' claim. Independent [Online, 16 March 2016]. Avaiable at: http://www.independent.co.uk/news/world/middleeast/british-academic-to-leave-turkey-after-25-years-over-terrorpropaganda-claim-a6935121.html [accessed: 21.03.2016].

Pope, Hugh (2014) Why Syria's disaster threatens a war in Turkey. The Guardian [Online, 10.10.2014]. Avaibale at: http:// www.theguardian.com/commentisfree/2014/oct/10/ syria-disasterwar-turkey-isis-pkk [last accessed: 14.04.2015].

Reuters (2016) Turkey should consider stripping citizenship from supporters of terrorism: Erdogan. Reuters [Online, 5 April 2016]. Available at: http:/ /mobile.reuters.com/article/idUSKCNOX21RE [accessed: 05.04.2016].

Rosenberg, Shawn W. and Gadi Wolfsfeld (1977) International conflict and the problem of arbitration. Journal of Conflict Resolution, 21(1): 75-103.

RSF (2016) Wold Press Freedom Index. Reporters Sans Frontieres (RSF) [Online, 2016]. Available at: http://rsf.org/en/ranking [accessed: 24.04.2016].

RT (2016) Ankara blast: Convenient excuse for Erdogan to hunt Kurds 'everywhere'? RT.com [Online, 18 February 2016]. Available at: https://www.rt.com/op-edge/332834-ankara-blast-erdogan-kurds/ [accessed: 18.02.2016].

Ryan, Jeffrey J (1994) The impact of democratization on revolutionary movements. Comparative Politics, 27(1): 27-44.

Safran, William (1991) Diasporas in Modern Societies: Myths of Homeland and Return. Diaspora 1: 83-99.

Ramsbotham, Oliver, Tom Woodhouse and Hugh Miall (2011) The Contemporary Conflict Resolution: The prevention, management and transformation of deadly conflicts. 3rd Edition, Cambridge: Polity Press. 
Sanchez, Raf (2016) Turkish government co-operated with al-Qaeda in Syria, says former US ambassador. The Telegraph [Online, 12 September 2014]. Available at: http://www.telegraph.co.uk/news/worldnews/europe/turkey/11093478 /Turkish-government-co-operated-with-al-Qaeda-in-Syria-says-former-USambassador.html [accessed: 24.01.2016].

Schiller, G. Nina and Fouron Eugene Georges (eds.) (2001) George Woke Up Laughing: Long-Distance Nationalism and the Search for Home. Durham and London: Duke University Press.

Schiller, G. Nina (2005) Long-Distance Nationalism. In: Melvin Ember, Carol R. Ember and Ian Skoggard (eds.) Encyclopedia of Diasporas Immigrant and Refugee Cultures Around the world: Volume I Overviews and Topics. New York: Springer, pp. 570-580.

Sheffer, Gabriel (2002) Diaspora Politics: At Home Abroad. New York: Cambridge University Press.

Snyder, Anna (2015) A Gendered Analysis of Refugee Peacebuilding: Transnational Networks for Peace. Review of Social Studies (RoSS), 2(1): 1-24.

Sumbeiywo, General Lazaro (2008) To Be A Negotiator: Strategies and Tactics. Lazaro Sumbeiywo and the Mediation Support Project, Center for Security Studies, ETH Zurich and swisspeace, Bern.

Tas, Latif (2013a) Resolving Family Disputes in the Gurbet: The Role of Kurdish Peace Committee and Roj Women. Onati Socio-Legal Series, 3(6): 11111135.

Tas, Latif (2013b) One State, Plural Options: Kurds in the UK. The Journal of Legal Pluralism and Unofficial Law, 45(2): 167-189.

Tas, Latif (2014a) Legal Pluralism in Action: Dispute Resolution and Kurdish Peace Committee. Farnham: Ashgate.

Tas, Latif (2014b) The Myth of the Ottoman Millet System: Its Treatment of Kurds and a Discussion of Territorial and Non-Territorial Autonomy. International Journal on Minority and Group Rights, 21 (4), pp. 497-526.

Tas, Latif (2015) What kind of peace? The case of the Turkish and Kurdish peace process. Open Democracy [Online, 9 July 2015]. Available at: https://www.opendemocracy.net/latif-tas/what-kind-of-peace-case-ofturkish-and-kurdish-peace-process [accessed: 09.07.2015]. 
Tas, Latif (2016) How International Law Impacts on Statelessness and Citizenship: the case of Kurdish nationalism, conflict and peace. Cambridge University Journal, International Journal of Law in Context, 12(1), pp.41-82.

Tastekin, Fehim (2016) Syrian Kurds expand diplomatic in Europe. AlMonitor [Online, 22 April 2016]. Available at: http://www.almonitor.com/pulse/originals/2016/04/turkey-syria-rojava-kurds-expanddiplomatic-network-europe.html\# [accessed: 24.04.2016].

Telgraf (2016) Davutoglu arka kapidan kacti. Telgraf Newspaper [Online, 18 January 2016]. Available at: http://www.telgraf.co.uk/davutoglu-arkakapidan-kacti-videofoto.html [accessed: 25.01.2016].

Tezcur, Gunes M. (2013) Prospects for Resolution of the Kurdish Question: A Realist Perspective. Insight Turkey, 15(2).

Tezcur, Gunes M. (2010) When democratization radicalizes: the Kurdish nationalist movement in Turkey. Journal of Peace Research, 47(6): 775-789.

The Guardian (2016a) Turkish journalists released from jail after court rules press freedom violated. The Guardian [Online, 26 february 2016]. Available at: http://www.theguardian.com/world/2016/feb/26/turkish-journalistsreleased-jail-court-rules-press-freedom-violated-dundar [accessed: 02.03.2016].

The Guardian (2016b) 1,845 Erdoğan insult cases opened in Turkey since 2014. The Guardian [Online, 2 March 2016]. Available at: http://www.theguardian.com/world/2016/mar/02/turkeys-justiceminister-defends-allowing-1845-insult-cases-to-go-ahead [accessed: 02.03.2016].

The UK Green Party (2016) Natalie Bennett: Turkey must show respect for internationally accepted human rights. Greenparty website [Online, 24 January 2016]. Available at: https://www.greenparty.org.uk/news/2016/01/24/natalie-bennettturkey-must-show-respect-for-internationally-accepted-human-rights/ [accessed: 24.01.2016].

The Washington Post (2016) Despotism deepens in Turkey. The Washington Post [Online, 7 March 2016]. Available at: https://www.washingtonpost.com/opinions/despotism-deepens-inturkey/2016/03/07/12e1d692-e25b-11e5-8d98-4b3d9215ade1_story.html [accessed: 21.03.2016]. 
Thurer, Daniel and Thomas Burri (2008). Self Determination. Oxford Public International Law. Available

at: http:// opil.ouplaw.com/view/10.1093/law:epil/9780199231690/law9780199231690-e873 [accessed: 24.04.2016].

Tisdall, Simon (2016) Ankara Bombing: Blaming Kurds Suits Erdogan's Political Ends. The Guardian [Online, 18 February 2016]. Available at: http://www.theguardian.com/world/2016/feb/18/ankara-bombingblaming-kurds-suits-erdogans-political-ends? $\mathrm{CMP}=$ share_btn_fb [accessed: 18.02.2016].

Today's Zaman (2015) KCK head sets out 6 conditions for laying down arms. Today's Zaman [Online, 16 March 2015]. Available at: http://www.todayszaman.com/anasayfa_kck-head-sets-out-6-conditionsfor-laying-down-arms_375418.html [accessed: 25.01.2016].

Tölölyan, Khachig (1996) Re-thinking diasporas: stateless power in the transnational moment. Diaspora 5(1): 3-34.

Turkone, Mumtazer (2009) Good things are going to happen. Today's Zaman [Online, 16 May 2009]. Available at: http://www.todayszaman.com/columnist/mumtazer-turkone/goodthings-are-going-to-happen_175466.html [accessed: 28.01.2016].

Ustundag, Gulten (2016) Interior Minister acknowledges 'ethnic group code' given to Turkey's minorities. Today's Zaman [Online, 15 February 2016]. Available at: http://mobile.todayszaman.com/national_interior-ministeracknowledges-ethnic-group-code-given-to-turkeys-minorities_412405.html [accessed: 16.02.2016].

Vali, Abbas (2015) Presentation at the conference 'Rediscovering The Kurds in the Middle East: New Developments and Prospects.' Organised by the London Middle East Institute, SOAS, University of London [Online, 24 April 2015]. Available at: https://www.soas.ac.uk/lmei/events/24apr2015-the-kurdsin-the-middle-east-new-developments-and-prospects.html [accessed: 7.05.2015].

Van Hear, N. (1998) New Diasporas: The Mass Exodus, Dispersal and Regrouping of Migrant Communities. London: UCL Press.

Wessels, Michael G. (1998) Children, Armed Conflict, and Peace. Journal of Peace Research 35(5): 635-646. 
Wickham-Crowley, Timothy (1992) Guerrillas and Revolution in Latin America: A Comparative Study of Insurgents and Regimes since 1956. Princeton: Princeton University Press.

Wickham-Crowley, Timothy (1994) Elites, elite settlements, and revolutionary movements in Latin America, 1950-1980. Social Science History 18(4): 543-574.

Yavuz, M. Hakan (2009) Secularism and Muslim Democracy in Turkey. Cambridge: Cambridge University Press.

Yavuz, M. Hakan and Nihat Ali Ozcan (2007) Crisis in Turkey: The Conflict of Political Languages. Middle East Policy, 14(3): 118-135.

Zalewski, Piotr (2016) Turkey justice ministry pledges action on 'terror 'sympathisers'. Financial Time [Online, 6 April 2016]. Avaiable at: http:// www.ft.com/cms/s/0/0a57a6be-fbf6-11e5-b5f5-

070dca6d0a0d.html\#axzz46I6v4zJ7 [accessed: 10.04.2016].

Zartman, I. William (2007) Peacemaking in international conflict: Methods, Technics. Washington: United States Institute for Peace. 